\title{
50 Years of the Paul Karrer Gold Medal: 1959-2009
}

\author{
Jay S. Siegel*
}

Abstract: Founded on the occasion of Paul Karrer's 70th Birthday, the Paul Karrer Medal in Gold celebrates its 50th anniversary having recognized the outstanding science of 34 molecular scientists.

Keywords: Karrer, P. · Paul Karrer Gold Medal

\section{Introduction}

The first Paul Karrer Lecture took place on the occasion of the public celebration of Paul Karrer's 70th birthday, 25th April, 1959, in the Auditorium of the University of Zurich. The guest speaker and first recipient of the Paul Karrer Medal was Arthur Stoll, a congenial colleague of Paul Karrer. Both had returned to Switzerland from prestigious German research institutions in 1917 in order to continue their illustrious careers in Switzerland: Paul Karrer as a professor at the University of Zurich, and Arthur Stoll as the director of pharmaceutical and chemical research at Sandoz AG in Basel. Karrer and Stoll both died in 1971.

Between the first Karrer lecture and today, there have been fifty years of exciting and pioneering developments in the field of organic chemistry and the thereby influenced related fields, such as molecular biology and structural biochemistry. Evidence of these developments is documented by the lectures of the recipients of the Paul Karrer Medal who were chosen over the course of these fifty years. Among the recipients are ten Nobel Prize winners for chemistry and for medicine, and they have represented numerous important research institutions of Europe and the USA.

In 1959, prizes in chemistry were not so abundant as they are today. Of the over 60 National ACS awards boasted by the

\footnotetext{
${ }^{\star}$ Correspondence: Prof. Dr. J. S. Siegel

Institute of Organic Chemistry

University of Zurich

Winterthurerstrasse 190

$\mathrm{CH}-8006$ Zurich

Tel.: +41446354281

Fax: +41446356888

E-mail: jss@oci.uzh.ch
}

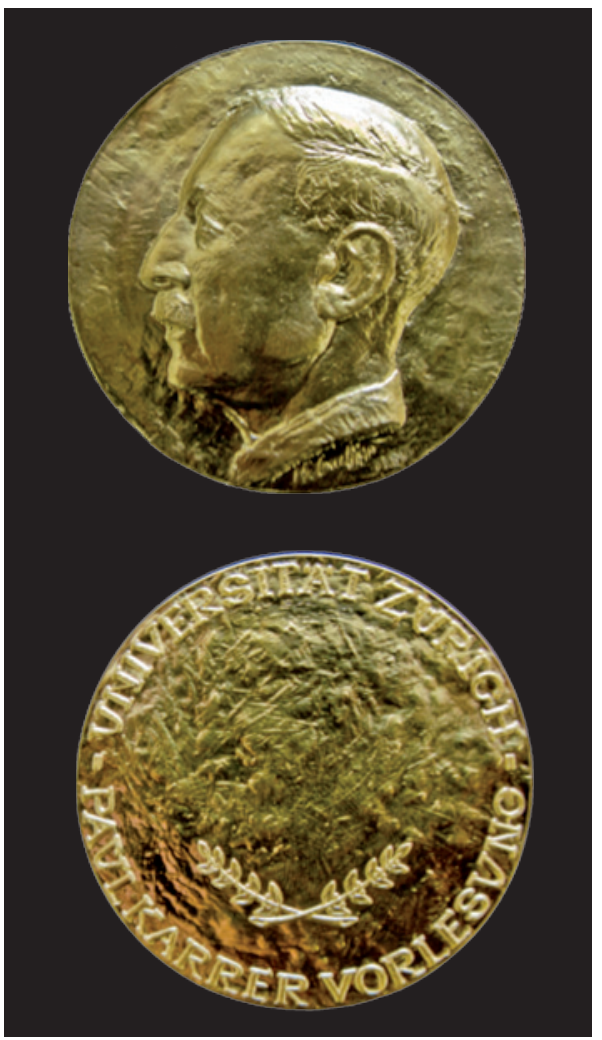

Paul Karrer Gold Medal

American Chemical Society today, barely a dozen have a longer history in recognizing achievements in chemical research than the Karrer Medal. Among those, the prestigious Roger Adams Award was founded the same year as the Karrer medal.

Internationally, the Nobel Prize, founded in 1901, is the signal award across academic disciplines. Comparable traditional awards for chemistry include the New York ACS regional Nichols Medal (1902) and the national ACS Priestley Medal (1922)

Prestigious awards of historical importance, like the Karrer Medal, have served an important role over the years not only to recognize carrier achievements, but also to promote chemistry by highlighting publically advances in research. These accom- plishments improve our overall standard of living through a number of derived applications to help solve technologically related social problems. However, equally important is that recognition of excellence in research and scholarship raises the bar on intellectual discourse in society, and thereby enriches our daily lives. Paraphrasing UZH alumnus, Albert Einstein, the level of intellect needed to solve a problem must be higher than that needed to create it. All the more important then that we preserve and support institutions, such as awards of excellence, that strive to identify pioneers in science and technology.

Paul Karrer lived the ideal that the award bearing his name represents. Born to Swiss parents in Moscow, he returned to Zurich at a young age. An accomplished Kantonsschüler (high school student) in Aargau, he entered UZH in 1911 and studied chemistry with Alfred Werner. During that time he almost gave up his studies due to financial problems in the family, initiated by an unexpected departure of his father.

Karrer's passion for a broad spectrum of natural science and its application to societal problems led him into medicine and natural product chemistry, where he could study botany through the chemical substances that each plant produced as colorants or other secondary metabolites. He recognized early on the importance of physics and physical chemistry to the determination of the structure of matter, and that structure determines function physically as well as physiologically; this is a broader corollary of his post-doctoral mentor, Paul Ehrlich's theory of medicinal magic bullets, in which molecules of defined structure would treat disease selectively.

These broad interests appear also in Karrer's text book on organic chemistry, which from 1929 and throughout its 13 revisions, maintained a selection of appendices that connected the chemical theory of the main text to statistical and demographical issues, such as industrial chemical pro- 
duction or societal dependent consumption of alcohol. Thus, a connection between intellectual advances in science and an increased social economy was forged.

Karrer's fundamental research in vitamins further connected nature, chemistry, and human health, while creating an enormous prosperity for Switzerland through its chemical, pharmaceutical and food science industries. Karrer noted in his speech as Rektor (President) of UZH in 1950 the good fortune of the Swiss (specifically Zurich) people to have such great institutions of higher learning and research in the sciences, and how directly the quality of life enjoyed by every citizen is connected to their support of excellence in such institutions.

The need not only to do great research, but to recognize and foster that research, was dearly important to Karrer. Perhaps influenced by his own personal situation as a student, Karrer founded in 1933, together with Swiss Industry, the Stiftung $f$. Stipendien a. d. Gebiet Chemie (Fund for Stipends in the area of Chemistry). This fund predates the Swiss National Science Foundation by decades, and has provided money for young chemists to devote themselves to the study of chemistry without worry about financial pressures that often drive intelligent but underprivileged students away from study and into labor.

Another vehicle for the recognition and fostering of great science has been focused conferences that bring together the great minds of the day around a table to debate important issues. Among such meetings, the Solvay Conferences for Chemistry and Physics, established by Belgian industrialist E. Solvay back in 1911, stand as paramount examples of scientific excellence. It is not surprising that of 22 such conferences in chemistry, Paul Karrer presided over four during the years 1947-1956, including themes like isotopes, oxidation, proteins, and inorganic chemistry. The breadth in topics betrays Karrer's breadth of interests and expertise.

By the time Karrer's 70th birthday arrived in 1959, he had established an incredible track record of achievements in the execution of research as well as in the support of research, at all levels. A medal in the Karrer name is heavy indeed by the gravitas of the namesake. Recipients of the Karrer Medal belong to a very elite grouping, with widespread name recognition for their outstanding achievements in molecular science.

The Karrer Medal is truly an international award. Through the awarding of this medal, the committee has recognized scientists associated with 13 different countries. Scientists from the US have been recognized 9 times, from Germany 8, Switzerland 6, the United Kingdom 4, Japan and Sweden twice, and Austria, Croatia, Spain,
France, Israel, Italy, and the Netherlands, each once.

A broad spectrum of institutions have served as homes to Karrer medalists. The favorite is none other than our sister institution ETH Zürich, with five previous recipients, most recently Albert Eschenmoser in 2008 as the special UZH 175th Jubilee Awardee. Next comes a triumvirate of academia: Caltech, Cambridge, and Harvard each having three. Munich has had two, and the rest are spread over numerous illustrious halls of higher learning.

The topics of research have spanned the broad spectrum of chemistry, with a focus on topics that Paul Karrer himself pursued or considered interesting. The most favored areas have been synthetic chemistry (9), vitamins (8), natural products (5), biosynthesis (4), nucleic acids (4), hormones (4), metal complex/coordination chemistry (4), analytical methods (3), oxidation studies (2), separation science (2), and stereochemistry (2).

Ten of the recipients have also won Nobel Prizes: Tiselius, Todd, Ochoa, Theorell, Wald, Wittig, Prelog, Corey, Zewail, Grubbs. George Wald is an especially worthy highlight in that he was an American trained in Karrer's lab, who discovered the carotinoids with Karrer, before going on in his own career to elucidate the molecular structure of the visual pigments and mechanism for visual excitation.

Karrer was a great enthusiast for chemistry and was responsible for helping to establish the Physical Chemistry Institute. He understood the importance of spectroscopy and analytic methods for the characterization of natural product molecular structure and function. He was convinced of the need for a strong physical chemistry at UZH to ensure the overall strength of chemistry on campus. It is therefore fitting that numerous Karrer Medals have been given in the area of physical chemistry, including that to Nobelist Ahmed Zewail for femtosecond spectroscopy.

There is some confusion about Karrer's apparent lack of support for an independent Inorganic Chemistry Institute. However, it was not due to a lack of interest and enthusiasm for inorganic chemistry, but rather because he believed he, through his training with Werner and work on arsenic compounds, was an expert in inorganic chemistry. That Karrer considered himself an expert in inorganic chemistry is also supported by the above-mentioned Solvay conference on inorganic chemistry over which Karrer presided. Karrer's attitude mirrored the image of Werner, who though the father of inorganic chemistry, felt competent enough in organic chemistry to write a text on the topic. In any case, there is clear evidence that Karrer was a strong supporter of inorganic chemistry, and strongly supported the Karrer medal for his former UZH colleague turned ETH Professor, Gerold Schwarzenbach.

Medicine and medicinal chemistry were extremely important areas to Paul Karrer. He often mused that he had wished to be a medical doctor if not that the need to find a job so quickly had driven him into chemistry. His two sons Heinz and Jürg both took up this dream and passed it on to grandson Peter Karrer who practices medicine today. The medical applications of chemical research, such as those in biochemistry and clinical chemistry play a center role in no less than a dozen Karrer medal awards. Karrer strongly believed that chemistry had a place in basic medical sciences and in the finding of active and selective medicinal agents for treating disease. It is evident from Karrer's early letters to Paul Ehrlich asking initially about the biological testing of arsenic compounds and later inquiring for a position, that Karrer brought his passion for biologically and medicinally relevant chemistry to Ehrlich's labs where they were honed to a fine edge.

After 50 years, the Karrer medal has earned a reputation as an international award that recognizes great achievements in science centered about organic chemistry. Through these awards it has shown the central nature of organic chemistry to thriving areas of medical science, materials engineering, and molecular synthesis. UZH is proud to host this institution of excellence and looks with great anticipation to another 50 years of Paul Karrer Medal lectures.

\section{Board of Trustees}

The trustees consist of the Rector of the University of Zurich, two representatives from the professors of the University of Zurich, and two representatives from the donors. These representatives, who are appointed by the Rector of the University of Zurich upon recommendation, hold office for four years and may be re-appointed for further periods.

President: Prof. Dr. Andreas Fischer, Rector of the University of Zurich

Secretary: Prof. Dr. Jay S. Siegel, Institute of Organic Chemistry, University of Zurich

Treasurer: Dr. Rudolf Schmid, F. Hoffmann-La Roche AG, Basel

Members: Prof. Dr. S. Seeger, Institute of Physical Chemistry, University of Zurich; Prof. Dr. R. Alberto, Institute of Inorganic Chemistry, University of Zurich; Dr. Reto Naef, Novartis Pharma AG, Basel

Founders: CIBA Aktiengesellschaft, Basel, J.R. Geigy AG, Basel; F. HoffmannLa Roche \& Co., AG, Basel; Sandoz AG, Basel; Société des Produits Nestlé SA, Vevey; Dr. A. Wander AG, Bern 


\section{Paul Karrer Medal Awardees}

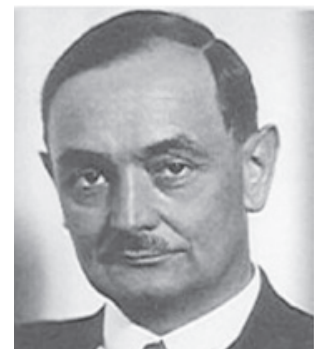

1. Arthur Stoll (1887-1971)

Aus der Chemie der Naturstoffe

(Experientia 1960, 16, 85-100)

http://de.wikipedia.org/wiki/Arthur_Stoll

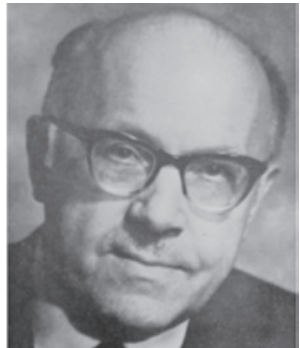

2. Clemens Schöpf (1899-1970)

Die Konstitution der Salamander-Alkaloide (Experientia 1961, 17, 285-295) http://de.wikipedia.org/wiki/Clemens_ Schöpf

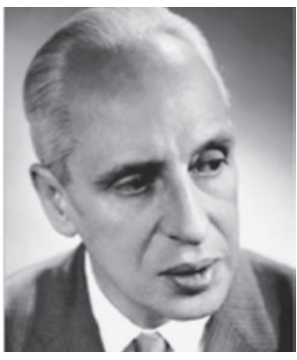

5. Severo Ochoa (1905-1993,

Nobel Prize 1959)

Chemical Basis of Heredity - the Genetic Code (Experientia 1964, 20, 57-68) http://en.wikipedia.org/wiki/Severo_ Ochoa

http://nobelprize.org/nobel_prizes/medicine/laureates/1959/ochoa-bio.html

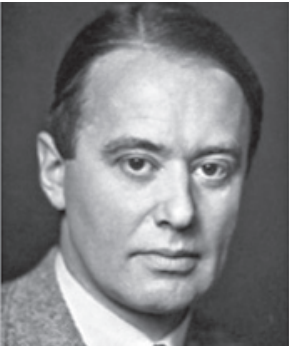

3. Arne W. K. Tiselius (1902-1971,

Nobel Prize 1948)

Einige neue Trennmethoden und ihre Anwendung auf biochemische und organisch-chemische Probleme (Experientia 1961, 17, 433-443)

http://de.wikipedia.org/wiki/Arne_Tiselius and http://en.wikipedia.org/wiki/Tiselius, Arne

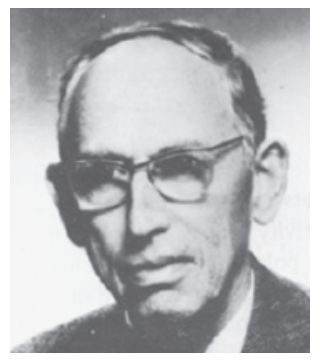

6. Edgar Lederer (1908-1982)

Über Ursprung und Funktion einiger Methylgruppen in verzweigten Fettsäuren, in Pflanzensterinen und in Chinonen der Vitamin $K$ - und Ubichinon-Gruppe (Experientia 1964, 20, 473-487) http://fr.wikipedia.org/wiki/Edgar_Lederer http://nobelprize.org/nobel_prizes/chemistry/laureates/1957/todd-bio.html

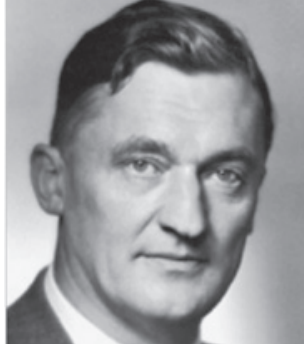

7. Axel Hugo T. Theorell (1903-1982, Nobel Prize 1955)

Die Alkoholdehydrogenasen - ihre Wirkungsweisen und Komplexverbindungen (Experientia 1965, 21, 553-561) http://en.wikipedia.org/wiki/Hugo_Theorell http://nobelprize.org/nobel_prizes/medicine/laureates/1955/theorell-bio.html

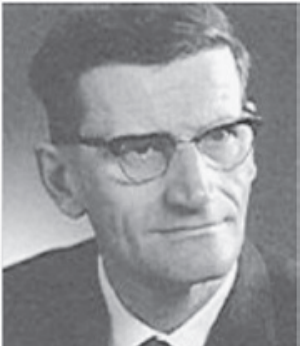

8. Gerold K. Schwarzenbach (1904-1978) Die Entwicklung der Valenzlehre und Alfred Werner (Experientia 1966, 22, 633-646)

http://en.wikipedia.org/wiki/Gerold_ Schwarzenbach

http://www.marcel-benoist.ch/d/pre/ d1963sch.htm

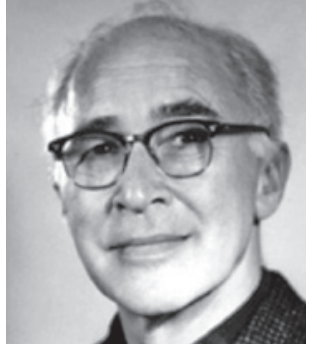

9. George Wald (1906-1997, Nobel Prize 1967)

The Molecular Basis of Visual Excitation http://en.wikipedia.org/wiki/George_Wald http://nobelprize.org/nobel_prizes/medicine/laureates/1967/wald-bio.html 


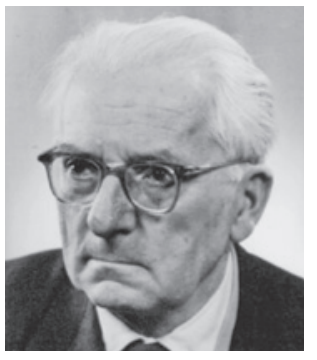

10. Kurt Mothes (1900-1983)

Die Alkaloide im Stoffwechsel der

Pflanzen (Experientia 1969, 25, 225-239) http://de.wikipedia.org/wiki/Kurt_Mothes

'Kurt Mothes - Scientist, Educator,

Humanitarian', V. E. Tyler, J. Nat. Prod. 1980, 43, 542-54.

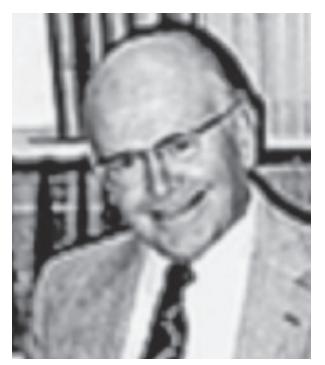

13. Bernhard Witkop (1917)

Neue Ziele in der Naturstoffchemie. Der organische Chemiker als Wegbereiter der Biochemie und Medizin ('New Directions in the Chemistry of Natural Products:

The Organic Chemist as a Pathfinder for Biochemistry and Medicine', Experientia 1971, 27, 1121-1138)

http://en.wikipedia.org/wiki/Bernhard_ Witkop

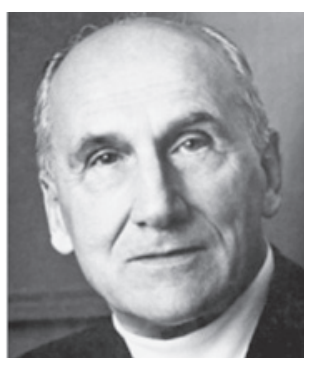

16. Vladimir Prelog (1906-1998,

Nobel Prize 1975)

Die Chiralität als Grundlage der Stereochemie

http://en.wikipedia.org/wiki/Vladimir_ Prelog

http://nobelprize.org/nobel_prizes/chemistry/laureates/1975/prelog-autobio.html
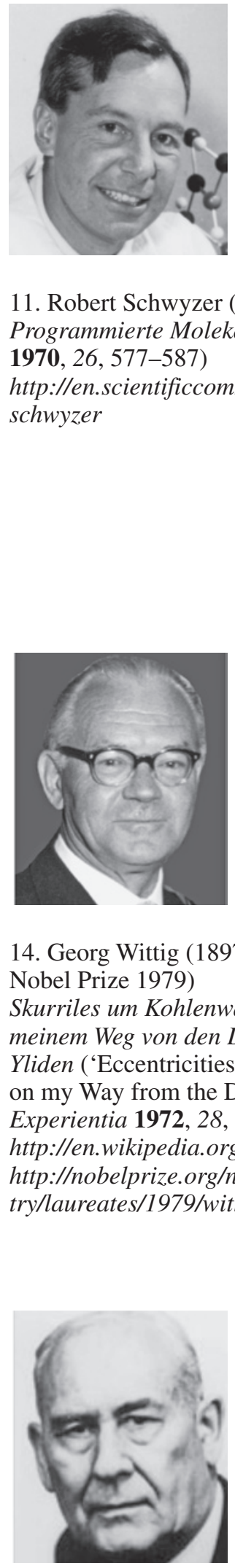

11. Robert Schwyzer (1929)

Programmierte Molekeln (Experientia 1970, 26, 577-587)

http://en.scientificcommons.org/robert_ schwyzer

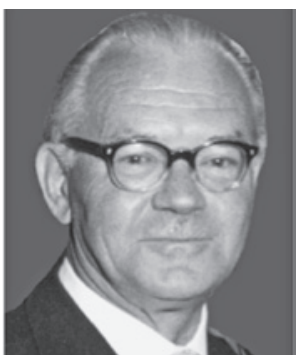

14. Georg Wittig (1897-1987,

Nobel Prize 1979)

Skurriles um Kohlenwasserstoffe auf meinem Weg von den Diylen zu den Yliden ('Eccentricities of Hydrocarbons on my Way from the Diyls to the Ylids', Experientia 1972, 28, 1265-1276) http://en.wikipedia.org/wiki/Georg_Wittig http://nobelprize.org/nobel_prizes/chemistry/laureates/1979/wittig-cv.html

17. Otto Isler (1910-1993)

Fettlösliche Vitamine und Carotinoide ('Progress in the Field of Fat-soluble Vitamins and Carotinoids', Experientia 1977, 33, 555-573)

http://www.vitamin-basics.com/index. php? id $=34$

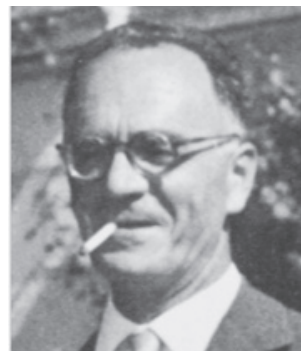

12. Adolfo Quilico (1902-1982)

Advances in Nitrile Oxides Chemistry (Experientia 1970, 26, 1169-1183) http://it.wikipedia.org/wiki/Adolfo_ Quilico

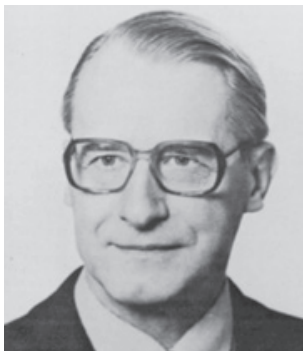

15. Egbertus Havinga (1909-1988) Vitamine D, Example and Challenge (Experientia 1973, 29, 1181-1193)

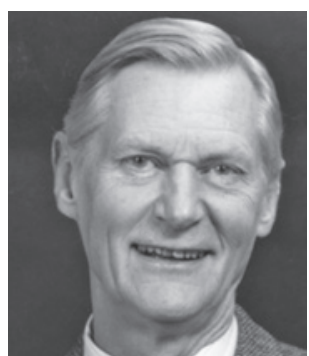

18. Alan R. Battersby (1925)

The Discovery of Nature's Biosynthetic Pathways (Experientia 1978, 34, 1-3) http://en.wikipedia.org/wiki/Alan_R. Battersby 


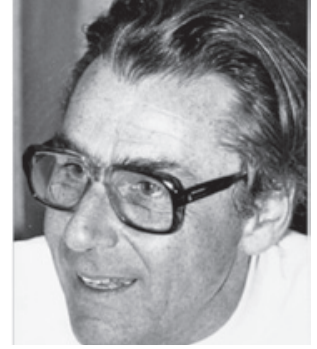

19. Hans Kuhn (1919)

Physikalisch-chemische Modelle als Denkansätze zur Frage der Entstehung lebender Systeme http://en.wikipedia.org/wiki/Hans_Kuhn
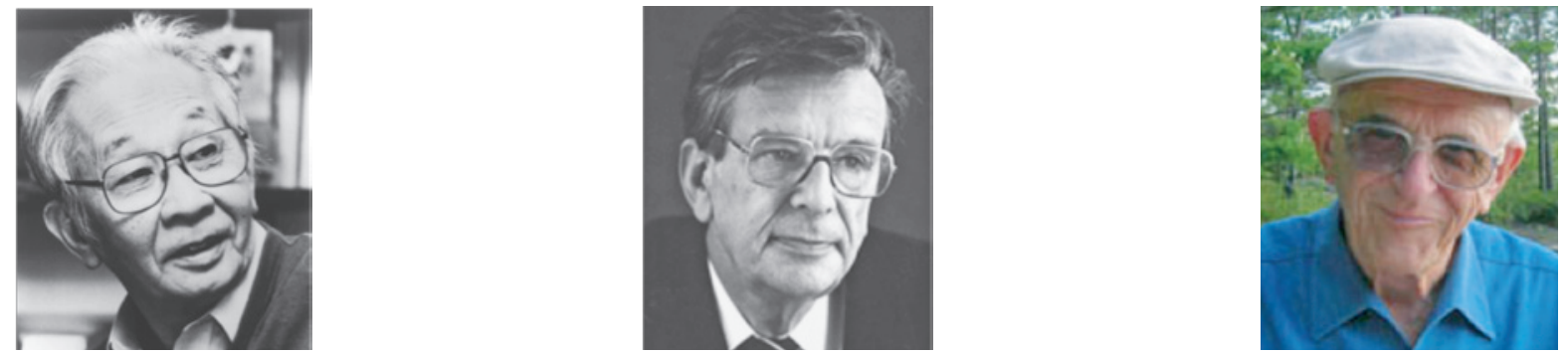

22. Koji Nakanishi (1925)

Studies with Retinal Proteins: Difference FTIR, etc.

http://en.wikipedia.org/wiki/Koji_ Nakanishi
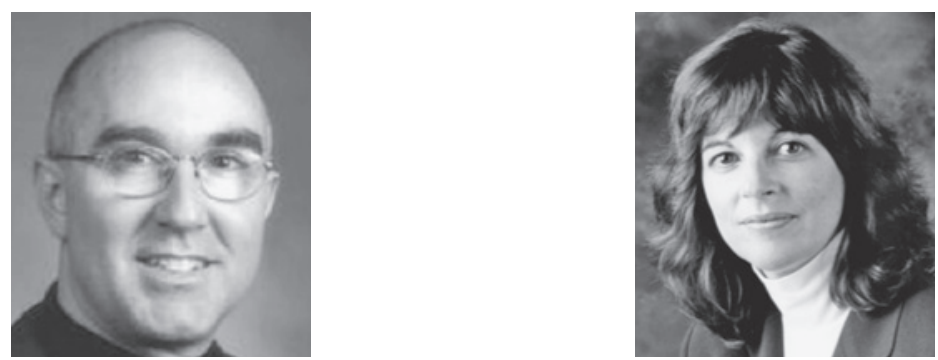

25. Stuart L. Schreiber (1956)

A Chemical Approach to Understanding and Controlling Signal Transduction http://en.wikipedia.org/wiki/Stuart_ Schreiber
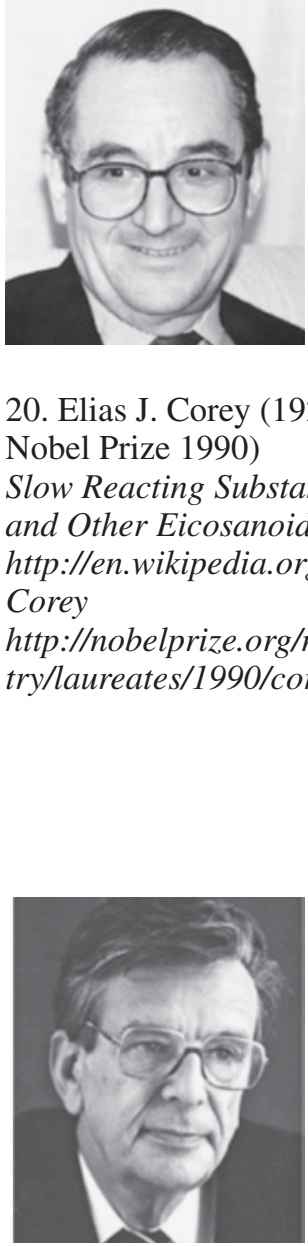

20. Elias J. Corey (1928,

Nobel Prize 1990)

Slow Reacting Substances, Leukotrienes, and Other Eicosanoids

http://en.wikipedia.org/wiki/Elias_J._ Corey

http://nobelprize.org/nobel_prizes/chemistry/laureates/1990/corey-

23. Duilio Arigoni (1928)

Zur Biogenese von Naturstoffen http://en.wikipedia.org/wiki/Duilio_ Arigoni
26. Jacqueline K. Barton (1952)

The Chemistry of DNA: Probing Recognition and Reaction with Transition Metal Complexes

http://en.wikipedia.org/wiki/Jacqueline_ Barton

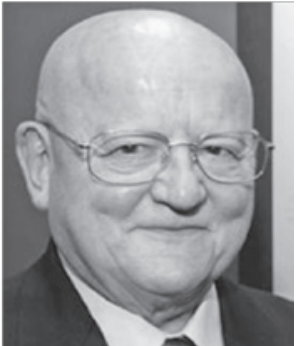

21. Jack E. Baldwin (1938)

Stereochemical and Mechanistic Studies on Some Enzymatic Reactions http://en.wikipedia.org/wiki/Jack_Baldwin
24. Hans Paulsen (1922)

Synthese von Glycoprotein-Segmenten zum Studium der Spezifität der Biosynthese von Glycoproteinen

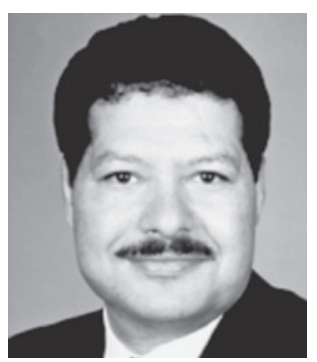

27. Ahmed H. Zewail (1946,

Nobel Prize 1999)

Chemistry and Biology in the

Femtosecond Age

http://en.wikipedia.org/wiki/Ahmed_H. Zewail

http://nobelprize.org/nobel_prizes/chemistry/laureates/1999/zewail-autobio.html 


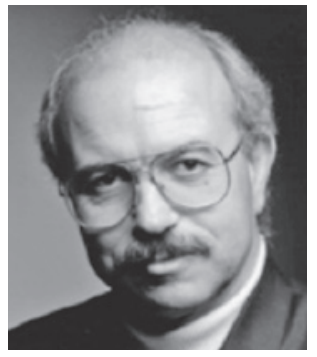

28. Kyriacos C. Nicolaou (1946) Chemistry, Biology and Medicine of Natural and Designed Molecules http://en.wikipedia.org/wiki/K._C._ Nicolaou

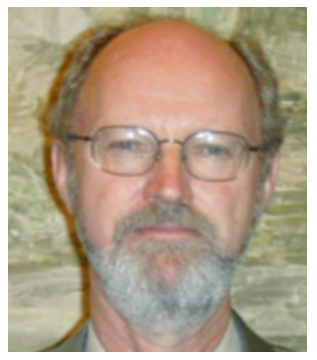

31. Robert H. Grubbs (1942,

Nobel Prize 2005)

Olefin Synthesis Using Ruthenium

Metathesis Catalysis

http://en.wikipedia.org/wiki/Robert_H_ Grubbs

http://nobelprize.org/nobel_prizes/chemistry/laureates/2005/grubbs-autobio.html

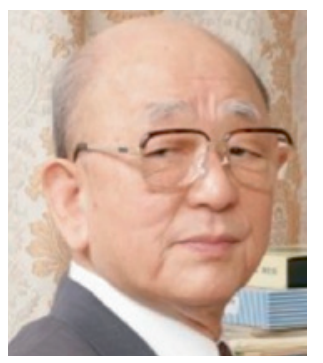

34. Akira Suzuki (1930)

Cross Coupling Reactions of

Organoboron Compounds

http:// en.wikipedia.org/wiki/Akira_Suzuki

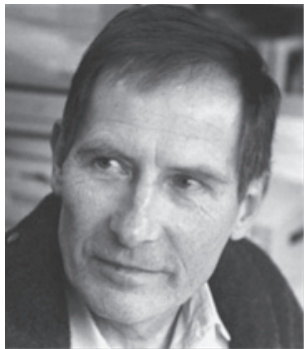

29. Dieter Osterhelt (1940)

Die biologischen Funktionen der VitaminA-Familie

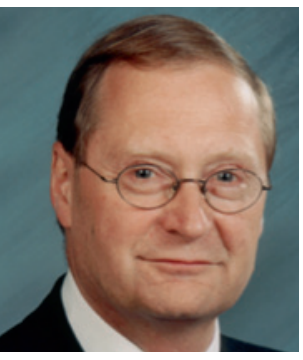

32. Steven V. Ley (1945)

The Changing Face of Organic Chemistry (Chimia 2008, 62, 162)

http://en.wikipedia.org/wiki/Steven_V._Ley

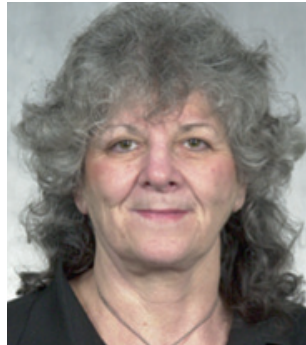

30. Ada Yonath (1939)

The Spectacular Ribosomal Architecture: Linking Positional Catalysis to Antibody Synergism http://en.wikipedia.org/wiki/Ada_Yonath

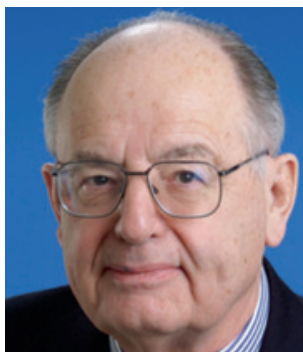

33. Albert Eschenmoser (1925) Naturstoffstrukturen hinterfragen http://en.wikipedia.org/wiki/Albert_ Eschenmoser 